DOI: 10.17707/AgricultForest.64.1.08

\author{
Oksana YEREMENKO, \\ Svitlana KALENSKY, Valentina KALYTKA ${ }^{1}$
}

\title{
SAFFLOWER PRODUCTIVITY DEPENDING ON SEED TREATMENT BY AKM PLANT GROWTH REGULATOR AND LEVEL OF MINERAL NUTRITION
}

\begin{abstract}
SUMMARY
Extremely uneven distribution of moisture during the growing season dramatically increases not only the risk of safflower seeds yield reduction, but its quality as well. One of the main reserves of solving this problem is the dose of fertilizers, particularly nitrogen, and use of plant growth regulators (PGRs) in the critical phases of plant development. It is the optimum combination of these factors that is a significant reserve for increasing yield stability and quality of safflower seeds. The aim of the research was to identify the impact of AKM PGR on productivity of safflower plants at different levels of mineral fertilization. The results of the study on the impact of the AKM plant growth regulator on growth, development and yield formation of safflower in low moisture conditions of Southern Steppe of Ukraine are presented. Optimal concentration of AKM PGR (0.0015 g/l) was determined. Seeds, processed by AKM PGR, had laboratory germination $5.7 \%$ higher than in the control. In 2016, the safflower plant height for all variants was higher than this figure in the other years of the study. This is because HTC in 2016 for the period BBCH 00-39 was higher than in 2015 by 1.4 times. Therefore 1 anthodium formed on average 13.2 to 21.6 seeds. AKM PGR increased, compared to control, both weight of seeds in 1 anthodium, and the number of anthodia during the study years, thanks to antistress properties of AKM. This preparation significantly affected yield only in unfavourable years, and the impact of fertilizers was insignificant. The AKM plant growth regulator is recommended for the use on safflower in $0.0015 \mathrm{~g} / \mathrm{l}$ concentration.
\end{abstract}

Keywords: Safflower, Productivity, Plant growth regulator, Growth and development of the plants, Stress resistance.

\section{INTRODUCTION}

In recent years, the global food market has increased demand for vegetable fats (Ermakov and Polyakov, 2013). Among oilseed crops, sunflower and safflower are of particular importance in food industry (Adamen et al., 2014).

\footnotetext{
${ }^{1}$ Oksana Yeremenko, (corresponding author: ok.eremenko@gmail.com), Svitlana Kalensky, National University of Life and Environmental Sciences of Ukraine, UKRAINE, Valentina Kalytka, Tavria State Agrotechnological University of Ukraine, UKRAINE

Paper presented at the $8^{\text {th }}$ International Scientific Agricultural Symposium "AGROSYM 2017".

Notes: The authors declare that they have no conflicts of interest. Authorship Form signed online.
} 
Their growing is closely connected with the increase in oil production that must be reached through higher yield. This, however, entails a number of problems (Ermakov and Polyakov, 2014, Dordas and Sioulas, 2009).

Crop production depends on weather conditions throughout the entire growing season. Weather risks, significantly affecting crop yields, are one of the least predictable and objective factors (Quiroga, 2001, Bezditko, 2011). Therefore, safflower seed production in many farms of the Steppe zone of Ukraine is characterized by reducing yield and its stability and, consequently, raising production costs (Dudnik and Chomyak, 2008).

There are two ways to enhance plant resistance to stresses: by selecting resistant varieties or hybrids at the genetic level or managing resistance via technological methods. Increasing plant resistance to stresses under differentiated use of plant growth regulators (PGRs) at the various growth stages is an effective way to increase yield (Svetlova et al., 2002).

Raising crop productivity under the PGR influence is associated with the increase in plant adaptation to the growing conditions and intensification of cell activity in the plant organism due to stimulation of biochemical processes thereby leading to the optimization of nutrition, respiration and photosynthesis processes (Klimenko, 2015). PGRs facilitate the higher realization of genetic potential of plants (Kalytka and Zolotuhina, 2011).

Mohsen Janmohammadi claims that silicon nanoconcentrations (nSiO2) increase leaf surface area by $48 \%$ and stimulate growth processes of safflower under adverse weather conditions and against various organic and mineral nutrition (Janmohammadi, 2016).

According to a group of scientists including Sibgha Noreen, Muhammad Ashraf, Mumtaz Hussain, Amer Jamil, Kazem Ghassemi-Golezani, and Ayda Hosseinzadeh-Mahootchi the use of salicylic acid to grow sunflower and safflower reduces the negative impact of stress factors by increasing activity of antioxidant enzymes. In addition, the processes of growth and photosynthetic activity of plants are also activated (Noreen et al., 2009, Kazem GhassemiGolezani and Ayda Hosseinzadeh-Mahootchi, 2015).

Fertilizers provide different effects on growth and development of safflower (Omid Mohsennia and Jalal Jalilian, 2012; Mostafa Heidari and Sepideh Mohamadi, 2014). The authors have established that the nitrogen in an amount of $150 \mathrm{~kg} / \mathrm{ha}$ increased yield by 55\% compared to control. With increasing this dose to $225 \mathrm{~kg} / \mathrm{ha}$ the yield increased by only 23\%. Different fertilizer norms influence not only the yield but also the seed quality, in particular fatty acid composition of seeds.

The efficiency of PGRs and mineral fertilization of oilseed crops under conditions of sufficient moisture and observation of cultivation technology is rather high (Bonfim-Silva et al., 2015). At the same time, few studies elucidate the cultivation of safflower with the use of PGRs and different mineral fertilization in the conditions of insufficient and unstable moisture. Thus, poor knowledge of this issue has led to the direction of our research. 
The development of agricultural techniques for growing safflower has become a pressing issue in arid conditions of South Steppe of Ukraine. The aim of this research is to develop and justify the elements of safflower cultivation technology capable to ensure for agrocenoses the level of productivity close to the genetic potential, given the growth and development patterns of plants.

\section{MATERIAL AND METHODS}

Field studies were carried out over the period 2014-2016 in the scientificproduction centre of Tavria State Agrotechnological University (Melitopol district, Zaporizhzhia region, Ukraine), and laboratory studies - in the Laboratory for the Soil and Crop Production Quality Monitoring (Scientific Research Institute of Agrotechnology and Ecology at TSAU).

The soil of study plots was represented by chernozem containing $2.91 \%$ of humus, $81.5 \mathrm{mg} / \mathrm{kg}$ of light hydrolyzed nitrogen, $138.4 \mathrm{mg} / \mathrm{kg}$ of movable phosphorus, and $165.8 \mathrm{mg} / \mathrm{kg}$ of exchangeable potassium as a weighted average; $\mathrm{pH}$ of the soil solution was close to neutral.

Soil moisture conditions varied between years both in the amount of rainfall and evenness of its distribution. The least rainfall in the vegetation period was recorded in 2015 (155 mm; HTC = 0.56), and the highest one - in 2014 (233 $\mathrm{mm}$; HTC $=0.81)$. The year of 2016 had uneven distribution of rainfall $(\mathrm{HTC}=$ 0.67) and high temperatures; minimum relative air humidity in the flowering season constituted 35.5\%. In general, agrometeorological conditions in 2015, compared to 2014 and 2016, were more optimal in terms of minimum relative air humidity in the flowering season (45.8\%) and evenness of rainfall distribution.

The agricultural techniques in the experiment were common for the Steppe zone of Ukraine except for the studied factors. The total size of an elemental area was $90 \mathrm{~m}^{2}$, count area $-54 \mathrm{~m}^{2}$. The effects of mineral nutrition (factor A), presowing AKM treatment of seeds (factor B) and agrometeorological conditions of the year (factor C) on the formation of safflower yield structure were studied in a three-factor field experiment according to the scheme (Table 1).

Table 1. Field research scheme (2014-2016)

\begin{tabular}{|l|l|c|}
\hline $\begin{array}{c}\text { Fertilizer system, kg/cwt a.s. } \\
\text { (factor A) }\end{array}$ & \multicolumn{1}{|c|}{$\begin{array}{c}\text { PGR } \\
\text { (factor B) }\end{array}$} & $\begin{array}{c}\text { Agrometeorological conditions of } \\
\text { the year (factor C) }\end{array}$ \\
\hline Control (without fertilizers) & without PGR & \\
\cline { 2 - 2 } & AKM & \multirow{2}{*}{$2014-2016$} \\
\hline $\mathrm{N}_{45} \mathrm{P}_{60} \mathrm{~K}_{45}$ & without PGR & \multirow{2}{*}{2014} \\
\cline { 2 - 2 } & AKM & \\
\hline
\end{tabular}

The AKM formulation with an application rate of $0.33 \mathrm{l} / \mathrm{t}$ was used. The seeds were incrusted 1-2 days before sowing (10 litres of working solution per 1 ton of seeds).

AKM is a semi-synthetic film-forming plant growth regulator with the anti-stress effect allowed for the treatment of seed and spraying of vegetating plants of cereals, legumes, oil-bearing and vegetable crops, and hops. The 
formulation includes dimethyl sulfoxide $(0.0018$ - $1.8 \mathrm{~g} / \mathrm{l})$, butylhydroxytoluol (0.0027 - $2.7 \mathrm{~g} / \mathrm{l})$, PEG 1500 (440 g/l), PEG 400 (190 g/l), and the rest is water (Kalytka V.V. et al., 2011).

The seed quality was assessed by the germination energy and laboratory germination capacity of the seeds sown in paper rolls according to the standard method. Crop tending, census and monitoring of the plant growth and development, and observations of the formation of structural elements of safflower yield were performed according to Rozhkov (Rozhkov, A.O. et al., 2016). The results were mathematically processed using Student's t-test with the assistance of the Agrostat software program.

\section{RESULTS AND DISCUSSION}

Presowing seed treatment of safflower activates self-regulation processes and provokes the increase in germination and resistance to adverse environmental factors. It should be noted that the AKM effect depends on the concentration of active substances (butylhydroxytoluol, dimethyl sulfoxide).We found out that, depending on different concentrations of active substances, the AKM incrustation of safflower seeds leads either to stimulation or inhibition of germination (Fig.1). Maximum laboratory germination of safflower seeds was recorded with using an AKM dose of $0.0015 \mathrm{~g} / \mathrm{l}$ (by active substance) that exceeded control by 5.7\%.

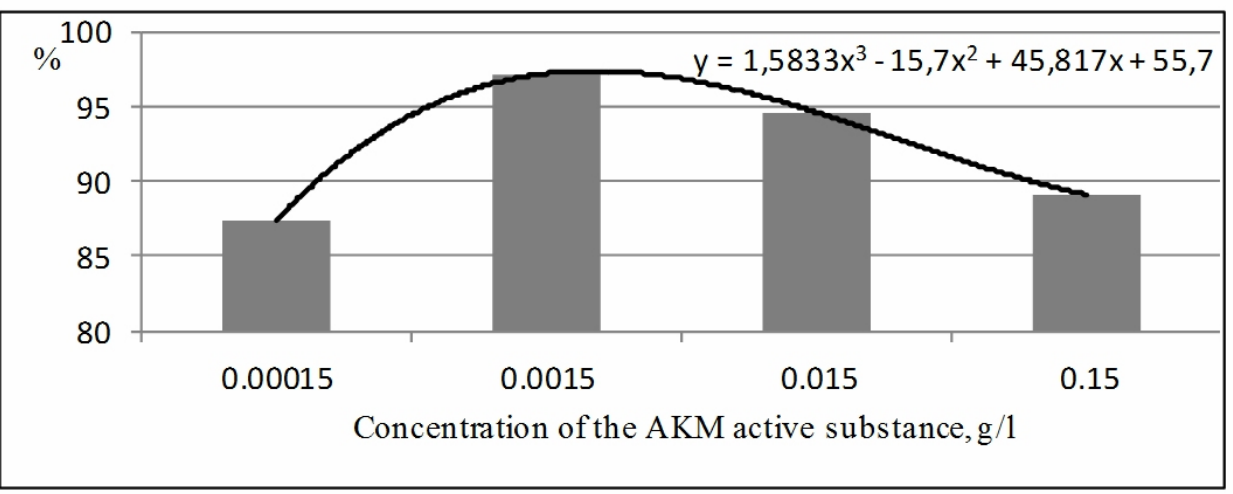

Figure 1. Dependence of laboratory germination of safflower seeds on concentrations of the AKM active substance: - Approximating polynomial curve of the $4^{\text {th }}$ order

Another essential advantage of AKM in a.s. concentration of $0.0015 \mathrm{~g} / \mathrm{l}$ is insignificant difference between germination energy and germination of seeds which in situ reduced the period between sowing and emergence of shoots by 1-2 days and helped to obtain more evenly distributed shoots. It is the reason why in the field experiment we treated seed with this concentration of AKM.

Sowing conditions for safflower were favourable during the studied years. In the sowing-shoots period (BBCH 00-09), HTC ranged from 1.43 (2016) to 
1.71 (2014), and the field germination did not vary significantly between the studied variants (Table 2).

Table 2. Field germination and biometrical indices of growth and development of safflower*

\begin{tabular}{|c|c|c|c|c|c|}
\hline \multirow{2}{*}{$\begin{array}{c}\text { Norm of } \\
\text { fertilizers, } \\
\mathrm{kg} / \mathrm{ha} \text { a.s. } \\
\text { (factor A) }\end{array}$} & \multirow[b]{2}{*}{$\begin{array}{c}\text { PGR } \\
\text { (factor B) }\end{array}$} & \multirow[b]{2}{*}{$\begin{array}{c}\text { Agrometeorological } \\
\text { conditions of the year } \\
\text { (factor C) }\end{array}$} & \multicolumn{3}{|c|}{ Index } \\
\hline & & & $\begin{array}{c}\text { Field } \\
\text { germination, } \\
\%\end{array}$ & $\begin{array}{l}\text { Plant } \\
\text { height, } \\
\text { cm }\end{array}$ & $\begin{array}{l}\text { Leaf surface area, } \\
\text { thou. } \mathrm{m}^{2} / \mathrm{ha}\end{array}$ \\
\hline \multirow{2}{*}{\begin{tabular}{|l|} 
K \\
(no fertilizers)
\end{tabular}} & without PGR & \multirow{4}{*}{2014} & 83.6 & 62.3 & 18.35 \\
\hline & with PGR & & 88.4 & 69.5 & 26.14 \\
\hline \multirow{2}{*}{$\mathrm{N}_{45} \mathrm{P}_{60} \mathrm{~K}_{45}$} & without PGR & & 85.7 & 68.5 & 25.61 \\
\hline & with PGR & & 89.3 & 73.4 & 27.59 \\
\hline \multirow{2}{*}{\begin{tabular}{|l} 
K \\
(no fertilizers)
\end{tabular}} & without PGR & \multirow{4}{*}{2015} & 85.2 & 63.1 & 19.52 \\
\hline & with PGR & & 89.7 & 71.4 & 27.08 \\
\hline \multirow{2}{*}{$\mathrm{N}_{45} \mathrm{P}_{60} \mathrm{~K}_{45}$} & without PGR & & 87.1 & 69.4 & 24.25 \\
\hline & with PGR & & 90.2 & 70.8 & 26.94 \\
\hline \multirow{2}{*}{$\begin{array}{l}\text { K } \\
\text { (no fertilizers) }\end{array}$} & without PGR & \multirow{4}{*}{2016} & 85.9 & 82.6 & 21.35 \\
\hline & with PGR & & 90.2 & 90.1 & 29.64 \\
\hline \multirow{2}{*}{$\mathrm{N}_{45} \mathrm{P}_{60} \mathrm{~K}_{45}$} & without PGR & & 89.3 & 88.5 & 30.28 \\
\hline & with PGR & & 89.9 & 89.6 & 32.59 \\
\hline \multirow{3}{*}{\multicolumn{4}{|c|}{$\begin{array}{r}\text { LSD }_{05} \text { of partial differences, for the factor: A } \\
\text { B }\end{array}$}} & 0.32 & 0.71 \\
\hline & & & & 0.47 & 0.68 \\
\hline & & & & 0.38 & 1.02 \\
\hline
\end{tabular}

*- biometrical indices are given for the flowering stage of safflower (BBCH-65)

The AKM effect accelerated the growth and development of safflower plants, and all the growth stages in the variants with PGR started 3-4 days earlier as compared to control.

In 2016, the height of safflower plants in all the variants exceeded the height values recorded in other studied years. This is due to the fact that HTC in 2016 for the period BBCH 00-39 was 1.4 higher than HTC in 2015.

Leaf surface area of safflower crops had the largest range of fluctuations in the flowering stage, reaching its peak (32.59 thousand $\mathrm{m}^{2} / \mathrm{ha}$ ) in 2016 in the variant with the AKM presowing seed treatment and mineral fertilization.

The indices of safflower productivity elements varied depending on the studied agricultural techniques. This, the least number of anthodia per one plant was recorded in control for the entire research period (Table 3). It was 1.3-1.5 times greater in the variant with the AKM presowing seed treatment and mineral fertilization. However, in case of the PGR presowing seed treatment or mineral fertilization, taken alone, this index increases by 1.2-1.4 times.

The number of seeds in the anthodium, weight of 1000 seeds and the weight of seeds in the anthodium in the variant with the AKM presowing seed treatment and mineral fertilization 1.1-1.5 times exceeded control values. Depending on the studied factor, one anthodium on average contained from 13.2 to 21.6 seeds. 
Changes in the growing conditions of safflower influenced its yield depending on the used agricultural techniques. For three years of research the highest yield was recorded in 2016 in the variant with the AKM presowing seed treatment and mineral nutrition (2.38 t/ha). The effect size of the studied factors on the yield equalled to $\mathrm{A}-21.9 \%, \mathrm{~B}-32.1 \%, \mathrm{C}-27.3 \%$, and $\mathrm{BC}-11.7 \%$.

Under the studied agricultural techniques the safflower realizes its genetic potential by $83-95 \%$. Thus, we advise agroproducers to grow safflower according with the developed technology, especially in zones of insufficient and uneven moisture, as a high-intensive plant, alternative to sunflower.

Table 3. Structural elements of safflower yield depending on the studied factors (2014-2016)

\begin{tabular}{|c|c|c|c|c|c|c|c|}
\hline \multirow[b]{2}{*}{$\begin{array}{l}\text { Norm of } \\
\text { fertilizers, } \\
\mathrm{kg} / \mathrm{ha} \text { a.s. } \\
\text { (factor A) }\end{array}$} & \multirow[b]{2}{*}{$\begin{array}{c}\text { PGR } \\
\text { (factor B) }\end{array}$} & \multirow[b]{2}{*}{$\begin{array}{l}\text { Agromet. } \\
\text { conditions } \\
\text { of the year } \\
\text { (factor C) }\end{array}$} & \multicolumn{5}{|c|}{ Index } \\
\hline & & & $\begin{array}{l}\text { Number } \\
\text { of } \\
\text { anthodia } \\
\text { per one } \\
\text { plant }\end{array}$ & $\begin{array}{l}\text { Number of } \\
\text { seeds in } \\
\text { the } \\
\text { anthodium }\end{array}$ & $\begin{array}{l}\text { Weight of } \\
1000 \text { seeds } \\
\text { (g) }\end{array}$ & $\begin{array}{c}\text { Weight of } \\
\text { seeds in } 1 \\
\text { plant (g) }\end{array}$ & $\begin{array}{l}\text { Yield, } \\
\text { t/ha }\end{array}$ \\
\hline \multirow{2}{*}{$\begin{array}{l}\text { K } \\
\text { (no fertilizers) }\end{array}$} & $\begin{array}{l}\text { without } \\
\text { PGR }\end{array}$ & \multirow{4}{*}{2014} & 7.6 & 13.2 & 37.4 & 3.92 & 1.04 \\
\hline & with PGR & & 10.7 & 19.6 & 39.5 & 8.28 & 1.75 \\
\hline \multirow{2}{*}{$\mathrm{N}_{45} \mathrm{P}_{60} \mathrm{~K}_{45}$} & $\begin{array}{l}\text { without } \\
\text { PGR }\end{array}$ & & 9.9 & 19.8 & 40.8 & 7.99 & 1.69 \\
\hline & with PGR & & 11.4 & 20.2 & 41.6 & 9.58 & 1.87 \\
\hline \multirow{2}{*}{$\left|\begin{array}{l}\text { K } \\
\text { (no fertilizers) }\end{array}\right|$} & $\begin{array}{l}\text { without } \\
\text { PGR }\end{array}$ & \multirow{4}{*}{2015} & 8.3 & 18.9 & 41.6 & 6.53 & 1.44 \\
\hline & with PGR & & 10.6 & 21.6 & 43.2 & 9.89 & 2.18 \\
\hline \multirow{2}{*}{$\mathrm{N}_{45} \mathrm{P}_{60} \mathrm{~K}_{45}$} & $\begin{array}{l}\text { without } \\
\text { PGR }\end{array}$ & & 10.9 & 21.5 & 42.1 & 9.87 & 2.16 \\
\hline & with PGR & & 11.7 & 21.4 & 43.6 & 10.94 & 2.21 \\
\hline \multirow{2}{*}{$\begin{array}{l}\text { K } \\
\text { (no fertilizers) }\end{array}$} & $\begin{array}{l}\text { without } \\
\text { PGR }\end{array}$ & \multirow{4}{*}{2016} & 9.6 & 18.9 & 36.4 & 6.60 & 1.45 \\
\hline & with PGR & & 11.2 & 21.2 & 40.5 & 9.62 & 2.21 \\
\hline \multirow{2}{*}{$\mathrm{N}_{45} \mathrm{P}_{60} \mathrm{~K}_{45}$} & $\begin{array}{l}\text { without } \\
\text { PGR }\end{array}$ & & 11.5 & 21.1 & 40.9 & 9.92 & 2.08 \\
\hline & with PGR & & 12.8 & 21.3 & 41.7 & 11.37 & 2.38 \\
\hline \multicolumn{3}{|c|}{$\mathrm{LSD}_{05}$ of partial differences, for: $\mathrm{A}$} & 0.4 & 0.8 & 0.4 & 0.3 & 0.12 \\
\hline \multirow{2}{*}{\multicolumn{3}{|c|}{$\mathrm{B}_{\mathrm{C}}$}} & 0.3 & 0.6 & 0.6 & 0.3 & 0.18 \\
\hline & & & 0.3 & 1.0 & 0.5 & 0.4 & 0.19 \\
\hline
\end{tabular}

\section{CONCLUSIONS}

Under different concentrations of active substances, the incrustation of safflower seeds with AKM leads either to stimulation or inhibition of germination. Maximum laboratory germination of safflower seeds was recorded using an AKM dose of $0.0015 \mathrm{~g} / \mathrm{l}$ (active substance) that exceeded control values by $5.7 \%$. In the period between sowing and emergence of shoots (BBCH 00-09), HTC ranged from 1.43 (2016) to 1.71 (2014) and, therefore, the indices of field germination did not vary significantly between the studied variants in 2014-2016. 
In 2016, the height of safflower plants in all the variants exceeded the height recorded in other years of research.

Maximum leaf surface area (32.59 thousand $\mathrm{m}^{2} / \mathrm{ha}$ ) was in 2016 in the variant with the AKM presowing seed treatment and mineral fertilization. In the stage of the formation of generative organs $(\mathrm{BBCH} 15-51)$ HTC ranged from 0.84 (2015) to 1.38 (2014). Depending on the studied factor, one anthodium formed on average from 13.2 to 21.6 seeds. The effect size of the factors on safflower yield equalled to A $-21.9 \%, \mathrm{~B}-32.1 \%, \mathrm{C}-27.3 \%$, a BC $-11.7 \%$.

\section{REFERENCES}

Adamen F.F., Rudik A.L., Proshina I.O. (2014). The impact of row spacing and norms on productivity and economic efficiency of cultivation of safflower in the south of Ukraine, Scientific and Technical Bulletin of the Institute of Oilseed Crops NAAS, Vol.20, pp. 151-157.

Bezditko O.E. (2011). Influence of weather risk factors on the crop yielding capacity, Bulletin of Zhytomyr National Agroecological University, Vol.2(1), pp. 374-82.

Dordas C.A., Sioulas C. (2009). Dry Matter and Nitrogen Accumulation, Partitioning, and Retranslocation in Safflower (Carthamus tinctorius L.) as Affected by Nitrogen Fertilization, Field Crops Research, Vol. 110, pp. 35-43.

Dudnik A.V, Chomyak P.V. (2008). Productivity of sunflower hybrids depending on biologically active substances under conditions of Southern Steppe of Ukraine, Ukrainian Black Sea Region Agrarian Science, Vol. 2(45), pp. 127-30.

Edna Maria Bonfim-Silva, Ellen Cristina Alves de Anicésio, Jakeline Rosa de Oliveira, Helon Hébano de Freitas Sousa, Tonny José Araújo da Silva (2015). Soil Water Availability on Growth and Development of Safflower Plants, American Journal of Plant Sciences, Vol. 6, pp. 2066-2073.

Ermakov A.S., Polyakov O.I. (2013). Safflower productivity depending on farming techniques and crop supervision. Scientific and Technical Bulletin of the Institute of Oilseed Crops NAAS, Vol.18, pp.79-84.

Ermakov A.S., Polyakov O.I. (2014). Safflower productivity depending on sowing terms and plant density. Scientific and Technical Bulletin of the Institute of Oilseed Crops NAAS, Vol.20, pp. 158-162.

Heidari M., Mohamadi S. (2014). Effect of arsenic and nitrogen application on grain yield and some physiological parameters of safflower (Carthamus Tinctorius L.), Journal of Advanced Agricultural Technologies, Vol.1(1), pp.48-51.

Janmohammadi M., Amanzadeh T., Sabaghnia N., Ion V. (2016). Effect of nano-silicon foliar application on safflower growth under organic and inorganic fertilizer regimes, Botanica Lithuanica, Vol. 22(1), pp. 53-64.

Kalytka V.V, Zolotuhina Z.V. (2011). Productivity of winter wheat in case of pre-sowing seed treatment by anti-stress composition, Scientific Journal of National University of Life and Environmental Sciences of Ukraine, Vol. 162(1), pp.93-99.

Kalytka V.V., Zolotuhina Z.V., Ivanchenko O.A., Yaloha T.M., Zhernovy O.I. (2011). Anti-stress composition for pre-sowing seed treatment of agricultural crops, Patent. 58260 Ukraine, MPK51 A01C 1/06, A01N 31/00. №201010482; publ. 11.04.2011, Bull. №7.

Kazem Ghassemi-Golezani, Ayda Hosseinzadeh-Mahootchi (2015). Improving physiological performance of safflower under salt stress by application of salicylic acid and jasmonic acid, WALIA journal, Vol. 31(S1), pp. 104-109. 
Klimenko I.I. (2015). Influence of plant growth regulators and microfertilizers on yield of seed lines and hybrids of sunflower. Id of seed lines and hybrids of sunflower, Selektsia i nasinnytstvo, Vol. 107, pp.183-188.

Mohsennia O., Jalilian J. (2012). Response of safflower seed guality characteristics to different soil fertility systems and irrigation disruption, International Research Jornal of Applied and Basic Sciences, Vol.3(5), pp.968-976.

Noreen S, Ashraf M, Hussain M, Jamil A. (2009). Exogenous application of salicylic acid enhances antioxidative capacity in salt stressed sunflower (Helianthus annuus L.) plants, Pak J Bot, Vol. 41, pp. 473-479.

Quiroga A.R., Díaz-Zorita M., Buschiazzo, D.E. (2001). Safflower Productivity as Related to Soil Water Storage and Management Practices in Semiarid Regions, Communications in Soil Science and Plant Analysis, Vol. 32, pp. 2851-2862.

Rozhkov, A. O., Puzik, V. K., Kalensjka, S. M., Puzik, L. M., Popov, S. I., Muzafarov, N. M., Bukhalo, V. Ja., \& Kryshtop, Je. A. (2016). Doslidna sprava v aghronomiji [Pilot case in agronomy]. (Vol. 1). Kharkiv: Majdan.

Rozhkov, A. O., Puzik, V. K., Kalensjka, S. M., Puzik, L. M., Popov, S. I., Muzafarov, N. M., Bukhalo, V. Ja., \& Kryshtop, Je. A. (2016). Doslidna sprava v aghronomiji [Pilot case in agronomy]. (Vol. 2). Kharkiv: Majdan.

Svetlova N.B, Kalenska S.M, Pantaliyenko A.V, Okanenko A.A, Musienko M.M. (2002). Plant growth regulators and formation of adaptive reactions of plants to drought, Scientific Journal of National University of Life and Environmental Sciences of Ukraine, Vol.58, pp. 11-17. 